\title{
Fuzûlî̀nin Şiirinde Önemli Bir Anahtar Kavram: Toprak
}

\author{
An Important Key Word in Fuzûlîs Poetry: Soil \\ Metin SAMANCI
}

\section{Özet}

Fużūlì, Farsça Dìvān'ının mukaddimesinde şiirini Kerbelâ toprağı olarak vasıflandırır. 'Āşık Çelebi de tezkiresinde Fużūli için ḩāk-sār-ı kūy-ı fena ' fena mahallesinde toz toprak içinde kalmış; fena mahallesinin düşkünü' ifadesini kullanır. Toprağın düşkünlüğü, perişanlığı, hakir olmayı ifade eden yönü Fużūli’nin mahlasının olumsuz anlamlarını, manevi değeri ise olumlu anlamlarını hatırlatır. $\mathrm{Bu}$ sebeple toprak Fużūlì'nin şiir dünyasını iyi betimleyen bir kelimedir.

Mahlası hem olumlu hem de olumsuz bir anlam taşıyan Fużūlí, maddi yönden değersiz olan toprağa manevi anlamlar yüklemiş; böylece onun şiirlerinde toprak kendi mahlası gibi çift yönlü hale gelmiştir. Eserlerini incelediğimizde toprakla ilgili orijinal imajlar oluşturduğu ve toprakla ilgili deyimleri, ibareleri sıkça kullandığını gördük. $\mathrm{Bu}$ nedenle toprak Fużūlì' nin şiirinde önemli bir anahtar kelimedir diyebiliriz. Bu yazıda Fużūlì'nin şiirinde toprak ile ilgili hayalleri ve deyimleri ele aldık. Ele aldığımız deyimler arasında toprahdan götür-, hāk çek-, hāakden baş çek- gibi başka şairlerde örneklerine rastlamadığımız kullanımlar da mevcuttur.

Çalışmamız iki bölümden oluşmaktadır. İlk bölümde toprakla ilgili imajlar incelenmiştir. $\mathrm{Bu}$ incelemede Fużūlì'nin Türkçe ve Farsça Dìvānları, Leylā vü Mecnūn, Hadikkatü's-süe dā eserleri taranıp toprakla ilgili imajlar değerlendirilmiştir. Çalışmanın ikinci bölümünde ise toprakla ilgili deyimler ve ibareler beyitlerden örnek gösterilerek açıklanmıştır.

Anahtar Kelimeler: Fużūlī, Toprak, Kerbelâ, Deyim, Mazmun.

\begin{abstract}
Fużūli characterizes his poetry as Karbala soil in his Persian Dìvān's preamble. 'Āşı̣ Çelebi, in Fużūli biography of his tadhkira, uses the

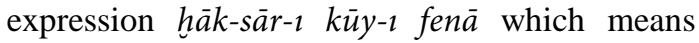
'mixed with earth, covered with dust; base, mean, low-born, abject'. The soil has two sides: first it describes indulgence, misery, worthlessness but on the other hand it has a intengible value. Fużūlì's pen name has two meanig like the soil. It means 'needless, unnecessary; worthless' but it has also 'virtuous; wholesome; moral'. Therefore, the soil is an expression which depicts Fużūlì's poetry well.

Fużūli, whose penname has both negative and positive meanings, assign spiritual meaning to the soil which is materially worthless so the soil has become bivious in his poetry just like his pen name. When we examine his works, we realised that his poetic imagery related to soil is original and idioms, expressions related to soil are frequently used in his poetry. Thus, we can say that the soil is an important key word in Fużūli's poetry. In this work, we discussed the poetic images, dreams and idioms about the soil in the Fużūli's poetry. There are some expressions that we have not encountered in other poets, such as toprahdan götür-, hāak çek-, hākden baş çek-.

Our work consists of two parts. In the first part, images related to the soil have been determined by scanning poet's works such as Turkish and Persian Dìvāns, Leylā vü Mecnūn, Hadìkatü'ssüe' $d \bar{a}$ and these images have been evaluated. In the second part, idioms and expressions related to the soil are explained by showing examples from couplets.
\end{abstract}

Key Words: Fużūlī, Soil, Karbala, Images, Idioms.

Arş. Gör. Bilecik Şeyh. Edebali Üniversitesi, metinsamanci@hotmail.com

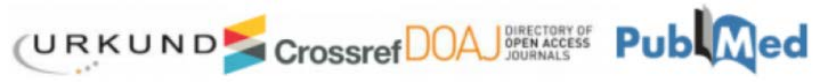




\section{Giriş}

Klasik Osmanlı şairlerinin beslendiği kaynaklar insanlığa toprak gibi olmayı öğütler. Toprak tevazunun ve teslimiyetin simgesidir. Toprak temizdir ve temizleyicidir; bütün pislikleri temizler, arıtır. Toprak gibi ayaklar altına, fakat gerçeklerin ayakları altına serilen, alçak gönüllülükte bulunan, benliğini yok eden kişi, arınır (Gölpınarlı 1977: 158). Mevlânâ (672/1273), Messnevi'de şöyle der: "Baharların tesiriyle taş yeşerir mi? Toprak ol ki renk renk çiçekler bitiresin. Yıllarca gönüller yırtan, kalblere elem veren taş oldun; bir tecrübe et, bir zaman da toprak ol!” (İzbudak, Gölpınarlı 1960: 152)

Kainattaki dört unsuru nefsin dört mertebesiyle ilişkilendiren sûfîler nefsin dördüncü mertebesi olan 'doyuma ulaşmış, huzur bulmuş nefis' anlamına gelen nefs-i mutmainneyi toprağa benzetirler: Nefs-i emmâre ateşe, nefs-i levvâme havaya, nefs-i mülhime suya, nefs-i mutmainne toprağa benzetilir (Uludağ 1997: 49). Aḥmed Yesevi'ye (XI. yy) göre tevazuya ermenin yolu kibirlenmeyi yere vurmak, kibirden zerre kadar bir eser bırakmamaktır. Tevazu makamını toprak metaforuyla açıklayıp toprak gibi herkesin basıp geçtiği, toprak gibi üzerine her türlü kirli nesnelerin atılmasına rağmen ondan sadece güzel kokulu ürünlerin hasıl olması kötülüğü giderip iyiliği ortaya çıkarma çabasını tevazu olarak adlandırmaktadır (Özköse 2017: 127).

Geleneğin etkisiyle klasik şiirde toprakla ilgili imajlar ve deyimler sıkça yer bulur. Güçlü ihtimalle cennette Âdem'e secde ile başlayan yere kapanma ve toprağı öpme eylemi; kabullenme, tapınma, saygı duyma, teslim olma, itaat etme, hasret giderme gibi pek çok duygu durumunu aktaran deyimlere kaynaklık etmiştir (Harmanc1 2014: 30). Fużūlìnnin; şiirlerinde toprakla ilgili orijinal ve yoğun anlamlı hayallere yer verdiğini, bu nedenle onun şiirinde toprağın önemli bir anahtar kavram olduğunu fark ettik. Kendi şiirini Kerbela toprağına

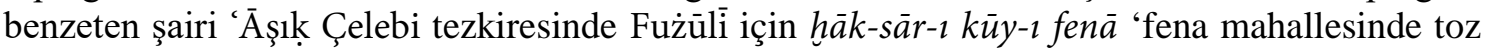
toprak içinde kalmış; fena mahallesinin düşkünü’ ifadesiyle tanımlar (Kılıç 2010: 1119). Şiiiri için "topraktır ama Kerbela toprağıdır" ifadesini kullanan şair

\section{Toprakla İlgili Hayallerin Beyitlerde İşlenişi}

\section{Adem'in (as) Topraktan Yaratılması}

Fużūli'de, Adem'in (as) topraktan yaratılması ile ilgili orijinal imajlar görülür. Sevgilinin eşiğinde toprak olmuş gönlün, o halde uzun bir süre bekledikten sonra Adem yani insan olacağını umut eder. İnsan olmanın şartı topraktan yaratılıp insan şekline gelmek değil sevgilinin eşiğinde toprak olmaktır:

der āstāne-i melekī hāàk geşteest

āncà ummìd hest ki ādem şeved dilem （Fużūlì: Farsça Dìvān: G. 331/4)

[= Gönlüm bir meleğin eşiğinde toprak oldu. Umarım orada Âdem/insan olur.]

Klasik şiir geleneğinde cennete benzetilen sevgilinin mahallesi, toprak halindeki aşığın Adem yani insan olması için beklemesi gereken yerdir. Kendisini o cennete benzetilen mahallesinden kovacak sevgiliye, henüz insan olmadığını bir toprak zerresi olduğunu söylerek onun mahallesinde kalabilmek için ikna etmeye çalışır: 
ger mukìm-i ravża-i kūyet şodem men'am me-kon

žerre-i hăkem teșavvur kon ki ādem nisstem （Fużūlì: Farsça Dìvān: G. 297/2)

[= Senin mahallenin bahçesinde/cennetinde ikamet ettimse bana engel olma. Bir zerre toprağım farz et ki Adem/insan değilim.]

Hadikkatü’s-sǘedā'da Adem'in (as) yaratılışının anlatıldığı bölümde toprağının dert ve hüzünle sulandığı söylenir. Rivayete göre Adem'in (as) toprağı 40 gün çamur halinde bekletilmiş. Otuz dokuz gün üzerine hüzün yağmurları yağdırılmış bir gün ise ferah damlaları serpilmiş. Fużūli insanın bu sebeple hüzünlü anlarının daha çok olduğunu söyler. Farsça Dìvān'ın mukaddimesinde dertlerden bahsedilen şiirin kalıcı olacağını söylemesinin (Tarlan 1950: 5) sebebi de insanın hüzünlü anlarının daha çok olduğuna inanmasının etkisiyledir.

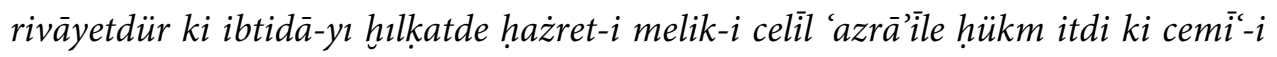
eczā-yı zemīnün her cüz'inden bir ḳabża hāk alup baṭn-ı nu'mānda cem' kıla ve bir sehāba emr itdi ki kıık gün ol toprag்un üzerine bārān töküp terbiyetine meşgul ola ve bu hıdmete me'mūr olan sehāb otuz dokuz gün deryā-yı elem ve çeşme-i ġamdan nem çekerdi ve ol țopraġa bārān-ı miḥnet tökerdi ḳırkıncı gün ki mev'id-i itmām idi bir niçe kaṭre baḥr-i ferāḥdan götürüp üzerine șaçup șūret-i tahmirin itmāma yetürdi ve peyker-i itmāmın zuhūra getürdi bu sebebden mukarrer oldı ki ținet-i beşeriyet ekșer-i evkāat menbet-i reyāhīin-i gam ola ve hakikikatde àsāar-ı sürūr nihāyet-i knllet bula (Fużūlì: Hadỉkatü’s-süe‘dā: s. 20)

[= Rivayet edilir ki yaratılışın başlangıcında Allahu Teâlâ Azrail'e yer yüzünün her parçasından toprak alıp Batn-1 Na'mân adlı yerde bir araya getirmesini emr etti. Bir yağmur bulutuna kırk gün o toprağın üzerine yağmur yağdırıp toprağı kıvama getirmesini emretti. Bu hizmetle görevli olan yağmur bulutu otuz dokuz gün elem denizinden ve gam çeşmesinden beslenirdi ve o toprağa sıkıntı yağmuru yağdırırdı. Bu işin tamamlanma günü olan kırkıncı gün ferah denizinden birkaç damla getirip toprağın üzerine saçtı ve toprağın yoğrulmasını tamamladı ve böylece görevini tamamladı. Bu sebeple insanlığın tıyneti çoğu vakit gam reyhanları bitirir ve mutluluğun izleri hakikaten oldukça azdır.]

\author{
ädemün ġam birle toprag்ın muhammer ḳıldılar \\ anda derd ü mihnete menzil mukarrer ḳldılar \\ mevḳid-i nìrān-i endūh eyleyüp terkībini
}

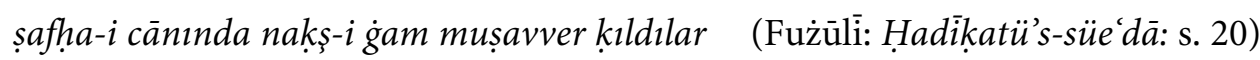

[= Adem'in toprağını hüzünle yoğurdular ve dert ve sıkıntıların onda mekan tutmasına karar verdiler. Bedenini sıkıntı ateşlerinin yandığı bir ocak yaptılar ve can sayfasında dert nakışları işlediler.]

\title{
Aşığın Toprakla Tanımlanması
}

Maḳālātında insanın dört unsurdan meydana geldiğini söyleyen Hacı Bektaş-1 Veli (669/1271 [?]), her insanda bu dört unsurdan birinin öne çıktığını söyler ve aşıkları toprağa benzetir: "Dördüncü taife; muhiblerdir. Bunlar hakikat tâifesidir ve bunların aslı topraktandır. Toprak teslimiyet ve rızâyı temsil eder. Bu yüzden muhib de teslimiyet ve rızâ içinde olmalıdır." (Coşan 1987: 5) 
Sevgilisinin karşısında âşık; tam tevazu hâlindedir, toprak gibi alçak gönüllüdür, açık ve saftır yani herhangi bir gizli niyetten uzaktır, tam teslimiyet hâlindedir, ölünün kendisini toprağa tam bırakışını andırır (Dağlar 2017: 42). Sevgili karşısında tam bir teslimiyet halinde olan ve sevgilinin yüceliği karşısında hakir bir konumda olan aşığı şairler hep toprakla betimler. Leylä vü Mecnūn'da geçen, Mecnûn'un kendisini toprak Leylâ'yı da güneş ve aya benzettiği aşağıdaki beyitler bu şiir geleneğine güzel bir örnek olacaktır:

dut kim ḩas ü hăr-ı reh-güzārem

toprag kimi yoluyda hôārem

hurşìd-i cemālüy èy meh-i nev

toprag்a nola birahsa pertev

(Fużūlì: Leylā vü Mecnūn: 1381)

[= Diyelim ki yolundaki çer çöpüm. Toprak gibi hakir bir şekilde yoluna serildim. Ey yeni ay gibi güzel sevgili, güzelliğinin güneşi toprağa 1şık salsa ne olur?]

Leylā vü Mecnūn'da Mecnûn, Leylâ'ya yazdığı bir mektupta kendisinden toprak huylu olarak söz eder. Burada kendisini toprağa benzetmesi Leylâ'ya layık olmadığını ifade etmek içindir. Bu nedenle toprak gibi yüzünün kara olduğunu söyler:

men ḩār-mizāc u hāk-ḩūyem

bes tünd-zebān u tîre-rūyem

(Fużūlì: Leylā vü Mecnūn: 1889)

[= Ben diken tabiatlı ve toprak huyluyum. Bu nedenle sivri dilliyim ve yüzüm kara.]

Bununla birlikte, ilerleyen bölümlerde Mecnûn yine kendini toprakla bir tutsa da bu sefer toprağın temiz oluşundan söz eder. Bilindiği gibi İslam'da toprak temiz ve temizleyicidir. Su bulunmadığı zaman toprak ile teyemmüm yapılır.

men 'ışk güzer-gehinde hākem

èl cümle bilür meni ki pākem

(Fużūlī: Leylā vü Mecnūn: 2723)

[= Ben aşk yolunun toprağıyım. Cümle alem benim temiz olduğumu bilir.]

Fużūlì, Mecnûn'u kendi diliyle toprağa benzeterek onun kendisini hakir gördüğünü bununla birlikte temiz olduğunu söyler. Böylece toprak benzetmesiyle Mecnûn'un görünüşte hakir ve değersiz olsa da manevi yönden değerli olduğu vurgulanır. Aynı benzetmeyi kendisi için de yapmıştır. Düşmanlarının gözünde yoldaki bir toprak kadar zelil olsa da görmesini, bakmasını bilenlerin gözlerinin görüşünü artıran bir sürme gibidir:

$$
\begin{aligned}
& \text { tūtiyā tek çeşm-i erbāb-ı nazardur menzilüm } \\
& \text { gerçi ḩāk-i reh-güzārem dìde-i bed-ḩāhuma } \quad \text { (Fużūlì: Dīvān: G. 242/3) }
\end{aligned}
$$

[= Her ne kadar bana düşmanlarımın gözünde yoldaki bir toprak gibi zelil olsam da benim yerim sürme gibi, bakmasını bilenlerin gözündedir.]

Şair, kendisini toprak gibi hakir görenlere ihtarda bulunmayı da ihmal etmez. Toprağın kimsenin gözünde değeri yoktur ama toz haline geldiğinde göze zarar verir. Beyitte geçen $\dot{g} u b \bar{a} r$ 
hem 'toz' hem de 'kırılma, gücenme' anlamındadır. Toprak nasıl toz halindeyken göze zarar veriyorsa toprak gibi hakir olan şair, gücendiğinde kendisine hakaretle bakana ah eder:

gerçi bir hāk-i rehem kimse meni almaz göze

çoh ḥaḳāretle nazar ḳılma ġubārumdan șahıın (Fużūlì: Dīivān: G. 223/6)

[= Her ne kadar insanların gözünde değeri olmayan yoldaki bir toprak olsam da beni hor görme, beni incitmekten sakın.]

men ki bāşem ki me-rā kūy-i tū mesken bāşed

hăk-i kūyet heme dem der nazar-i men bāşed （Fużūlì: Farsça Dìvān: G. 143/1)

[= Ben kim oluyorum da senin mahallen benim meskenim olsun; mahallenin toprağ her an gözümün önünde olsun!]

Yağmurun etkisiyle topraktan nasıl bitkiler yeşerip fidanlar boy atıyorsa aşığın toprak olmuş bedeni yağmur gibi sürekli akan göz yaşlarının etkisiyle dert fidanı yetiştirir:

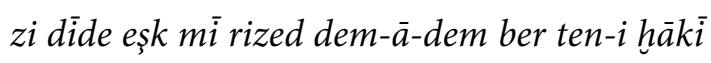

nihāl-i derd-i dil mì perverd āb u gil-i 'ạşik ～(Fużūlì: Farsça Dìvān: G.238/4)

[= Aşık toprak olmuş bedeni üzerine sürekli göz yaşı döker. Aşı̆̆ın su ve çamuru gönül derdi fidanı yetiştirir.]

\section{Ayna ve Toprak İlgisi}

Eskiden aynalar çoğunlukla metalden imal edilirdi ve aynaları parlatmak için toprak kullanılırdı (Ataş, Güven 2009: 230). Fużūlì, memduhu överken onun ayağının toprağının dostların gönül aynasını parlattığını söyler:

șafā-yı żikr-i hăke-i pāyıdur ol șaykal-i rạ̣met

ki mir'āt-i dil-i ahbābdan ref'-i ġubār eyler

(Fużūlì: Dìvān: K. 22/14)

[= Onun ayağının toprağını anmanın verdiği safa dostların gönül aynasından tozları gideren bir rahmet cilasidır.]

dūrem ez hăk-i der-i dūst Fù̇ūli çi 'aceb

ki ber āyine-i dil bāz ġubāri dārem ～(Fużūlì: Farsça Dì̄vān: G. 290/7)

[= Ey Fuzuli! Dostun kapısının toprağından uzak kaldım. Gönül aynam bir kez daha tozlansa bunda şaş1lacak ne var?]

\section{Kerbela Toprăğ}

Fużūlìye göre şiiri altın, gümüş, inci veya yakut değil topraktır. Şiirini tanımlarken maddi değeri yüksek olan mücevherler yerine basitliği ve hakirliği ifade eden toprağı tercih ederek tasannudan ve gösterişten uzak bir şiir dünyası olduğunu ima eder. Bununla birlikte "topraktır ama Kerbelâ toprağıdır" diyerek şiirinin manevi değerinin yüksek olduğunu ve her yerde hürmet göreceğini ifade eder: 
çün hāâk-i kerbelāst Fużūlì mekāam-i men

naẓmem be her kocā ki resed hurmeteş revāst

zer nist sim nist güher nist la'l nist

hākest şi ri $r$ bende veli hāak-i kerbelāst (Farsça Dìvān: Mukaddime, s. 77)

[= Fużūlì! Benim makamım Kerbela toprağı olduğu için şiirlerimin ulaştığı her yerde hürmet görmesi gerekir. Benim şiirim altın değil gümüş değil inci değil lâl taş1 değil topraktır. Ancak Kerbelâ toprağıdır.]

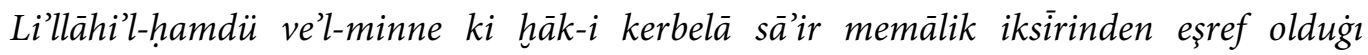
ma'lümdur ve rütbe-i şi'rümi her yèrde bülende èden hakikikatde bu mefhūmdur (Fużūlì: Dìvān: Mukaddime, s. 9)

[= Şükürler olsun ki Kerbela toprağının diğer ülkelerin (toprağı altına çeviren) iksirinden daha şerefli olduğu malumdur ve şiirimin derecesini her yerde yükselten de bu manadır.]

Hz. Hüseyin'in ve çevresindekilerin kanlarıyla sulanmış olan Kerbelâ toprağına Anadolu'da Alevi-Bektaşi geleneğinde çok hürmet edilir. $\mathrm{Bu}$ topraktan yapılmış mühürler ve tespihler ibadetlerde kullanılır. (İnce 2012: 256) Fużūli'’nin kendi şiirini maddi olarak hakir olmasına rağmen manevi değeri büyük olan bu toprağa benzettiğini söylemiştik. Kerbelâ toprağının manevi değerine işaret eden beyitlerine de rastlıyoruz:

$\bar{a}$ sùde-i kerbelā be her fi'l ki hest

ger hāk şeved ne-mi şeved kadreş pest

ber mì-dārend u subhaeş mi-sāzend

mi-gerdānend ez şeref dest be dest （Fużūlì: Farsça Dìvān: Rub. 21)

[= Ne günah işlerse işlesin Kerbelâ'da yatan toprak dahi olsa kadri azalmaz. Ona değer verirler ve toprağından tespih yaparlar. Şerefinden dolayı elden ele gezdirirler, el üstünde tutarlar.]

Sürme tedavi maksadıyla gözlere sürülür ve gözü yaşatır. (Bk. Sürme ve Toprak İlgisi) Kerbela toprağının orada yaşanan Kerbela Vakıasını hatırlattığı için temiz tabiatlı kişileri ağlatacağını söyleyen Fużūlì, bu durumu sürmenin gözleri yaşartmasına benzetmektedir. Göze toprak kaçtığında gözün yaşarması gerçeği de beyti okurken hatırda tutulmalıdır:

çeşme-nisbet dem-be-dem pākize-ținetler gözin

eşk-bār eyler melāl-i żikr-i hăäk-i kerbelā

ag̀ladursa kerbelā toprag்ı derd ehlin n'ola

bu mukarrerdür ki dā’im göz yaşadur tūtiyā 320)

(Fużūlì: Hadiḳatü’s-süe‘dā: s.

[= Kerbela toprağını sürekli anmak temiz tabiatlı kimselerin gözlerinden her an çeşme gibi yaşlar akıtır. Kerbela toprağı dertlileri ağlatırsa bunda ne var? Şu bir gerçek ki sürme daima gözleri yaşartır.]

\section{Ölümden Sonra Ebedilik Arzusunun Toprak Aracılığıyla İşlenmesi}

Birçok inanış sisteminde toprak canlıdır; topraktan çıkan her şey yaşam doludur ve toprağa dönen her şey yeniden hayat bulur (Eliade 2009: 255). İnsandaki ölümsüzlük arzusu şairlerde, ölümle birlikte bedenin karıştığı topraktan eşya yapılması, toprağın kullanılması isteği şeklinde 
kendini gösterir. Mesela Ahmed Paşa sevgilinin kendi toprağıyla oynaması için bir an evvel ölmeyi dilemektedir (Dağlar 2017: 45):

billāh èy gam egleme hāk ile yek-sān èt beni

oynaya hāaümle şāyed dil-ber og̀landur henūz (Aḥmed Paşa: Dīvān: G.120/6)

[= Ey gam! Allah aşkına beni bir an evvel toprağa karıştır. Sevgili hâlâ küçükken belki toprağımla oynar.]

Aynı şekilde Nedim'in Fużūli’ye yazdığı bir nazirede toprak olduktan sonra sürme haline gelip sevgiliye yakınlaşacağı umudu görülür (Dağlar 2017: 46):

$$
\text { hasret-i ḩālünle ben hāak-i siyāh olsam dahi }
$$

baht āhir sürme-i çeşm-i ġazāl eyler beni (Nedīm: Dì̄ōn: G. 147/8)

[= Senin siyah beninin hasretiyle ben kara toprağa karışsam da talih beni sonunda (senin) ceylan gözlerin için sürme haline getirir.]

Fużūlì, Su Kasidesi'nde, klasik şiir geleneğinde sevgiliye hayattayken kavuşmanın imkansızlığından dolayı, dostlarından gömüldüğü topraktan kase yapmalarını ve hayattayken elini öpemediği sevgilisine bununla su ikram etmelerini ister:

dest-būsı àrzūsiyle ger ölsem dōstlar

kūze eyleñ toprag்um șunuñ anuñla yāre șu ～(Fużūlì: Dìivān: K. 3/13)

[= Dostlar, elini öpme arzusuyla ölürsem topră̆ımdan bir kase yapın ve onunla sevgiliye su sunun.]

Aynı imajı Farsça Divan'da daha farklı bir şekilde işler. Bu sefer öldükten sonra dostlarından sevgilinin okları için toprağından bir hedef levhasını yapmalarını umut eder:

$z i$ behr-i tî̀r-i ù ez hā̄k-i men sāzend āmācī

pes ez morden zi yārān-i muvāfik çeşm-i ān dārem （Fużūlì: Farsça Dīivān: G. 257/3)

[= Onun oku için benim toprağımdan bir hedef levhası yapsınlar. Öldükten sonra samimi dostlarımdan bunu gözlüyorum.]

Öldükten sonra toprak olarak hayata karışma düşüncesi Fużūli’’de o kadar güçlüdür ki rakiplerinin ve düşmanlarının ölmesinden asla memnun değildir. Sürekli kendisine zarar veren rakiplerin öldükten sonra toprak olup tozlarının yine kendi gözüne dolacağından korkmaktadır:

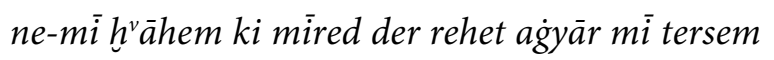
şeved hāak u der āyed bāz der çeşmem ġubār-i $\bar{u}$ 364/2)

[= Ağyarın senin yolunda ölmesini istemiyorum. Toprak olur da yine benim gözlerime dolar diye korkuyorum.] 
Sürekli sevgilinin yanı başında olan rakibin, öldükten sonra toprak haline gelip sevgilinin eteğine yapışmasından korkar:

ne-dārem zevkị ez merg-i raḳỉbān z'ān ki mì tersem

be-mīred hāk-i reh kerded be-gìred bāz dāmāneş

G.220/4)

(Fużūlì: Farsça Dīvān:

[= Rakiplerimin ölmesinden memnun değilim çünkü ölüp toprak olur da yine sevgilimin eteğine yapışır diye korkuyorum.]

\section{Ruhun Ait Olduğu Yer Gökyüzü, Bedenin Ait Olduğu Yer Toprak}

İslam alimlerine göre ruh latif beden ise kesif olarak nitelendirilir. Yani ruh ince ve şeffatır, maddi bir varlığa sahip değilir; bedense ruhun tam aksine yoğun bir maddi varlığa sahiptir. Bu nedenle ruh gökyüzüne bedense yer yüzüne yani toprağa izafe edilir. Gölpınarlı, Mesnevi'den bir beyit şerhinde şunları söyler: “ (...) Rûh latif olduğu için Allah Tebâreke ve Teâlâ onu kendisine izafe buyuruyor. Cisim kesif olduğu için onu dünyaya, toprağa, arza, yere izafe ediyorlar.” (Demirel 2005: 369). Ma'rifet-nāme'de ölüm, latif ruhun kesif bedenden ayrilması olarak açıklanmıştır: "Cevher-i lâtif olan rûh, cevher-i kesîf olan beden den cüda düşmekden (ayrı kalmakdan) ibâretdir.” (Revnakoğlu 1961: 152), Leylā vü Mecnūn'da Leylâ'nın ölümü anlatıldığı bölümde geçen aşağıdaki beyit bu inanış çerçevesinde işlenmiştir:

ten oldı mukìm-i arșa-i hāk

rūḥ oldı karīn-i evc-i eflāk （Fużūlì: Leylā vü Mecnūn: 2923)

[= Beden toprak diyarına yerleşti; ruh ise göklerin zirvesine yaklaştı.]

Fużūlì, ruhunun ait olduğu yere yani vahdet meclisine dönmesini ister. Latif ruh kesif bedenden ayrılıp vahdet meclisine yükselmelidir. Ruhun yükselmesi için bedenin toprağa karışması gerekir. Bu nedenle şair aşağıdaki beyitte dünya için 'toprak süprüntüsü, mezbele' anlamındaki hăk-dān kelimesini tercih etmiştir:

meskenün bezm-gāh-i vaḥdetdür

èy Fu̇̇ūlì bu hāa-dāndan geç (Fużūlì: Dìvān: G. 50/5)

[= Ey Fużūlī, senin yerin vahdet meclisidir. Bu mezbele dünyadan vaz geç.]

\section{Sevgilinin/Memduhun Toprak Aracılığıyla Övülmesi}

Aşık kendini toprakla bir tutarak sevgili karşısında benliğini hakir bir duruma getirir. Buna karşın sevgilinin yolunun, mahallesinin, ayağının, eşiğinin toprağını yüceltir. Klasik şiirde sıkça karşımıza çıkan bu geleneğin Fużūli' de başarılı bir şekilde işlendiğini görüyoruz. Meselâ sabah melteminin şefaat isteyerek Hz. Peygamber'in kabrinin toprağı etrafında döndüğünü söylediği şu beyit orijinaldir:

öz günāhına şefā'at isteyüp feryād èdüp

çizginür ḩāk-i mezāruñ üzre tā mahșer șabā

(Fużūlì: Dìvān: K. 5/21)

[= Sabah meltemi mahşere kadar kabrinin toprağı etrafında dolaşıp feryat eder ve günahlarına şefaat ister.] 
Aşık söz konusu olduğunda zelil ve hakir olmayı ifade eden toprak, sevgilinin eşiğinden söz edildiğinde güneşten daha yüksek bir makama yükseliyor. Güneş 1şıklarının eşiğe vurmasından bir devletlinin eteğine yapışmak diye söz ediliyor:

hosşdur èy gün țāli üñ kim düşdün ol hākk-i dere

ehl-i devlet dāmenin dutduñ yetersen bir yère

(Fużūlìi: Dìvān: G. 255/1)

[= Ey güneş, o eşiğin toprağına düştün. Bahtın açık; bir devletlinin eteğine yapıştın. Elbette bir makama gelirsin; muradina erersin.]

Toprak, sevgili söz konusu olduğunda -akıcı bir yapıda olmamasına rağmen- ölümsüzlük suyuna benzetilir. Belki de akıcı bir yapıda olmayan toprağı suya benzetmenin oluşturduğu tezat ifadeyi daha çarpıcı hale getirmektedir:

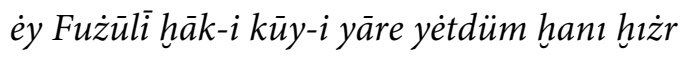

kim vèrem kāmın olam àb-ı hayāta reh-nümūn

(Fużūlì: Dìvān: G. 230/7)

[= Ey Fużūlì, sevgilinin mahallesinin toprağına ulaştım. Hızır nerede? Ona ölümsüzlük suyunun yerini göstereyim de muradına ulaştırayım.]

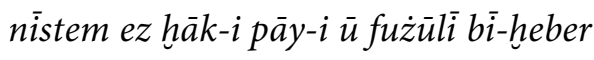

ḩı̇̇r-i vektem reh be āb-i zindegāni mì borem (Fużūlì: Farsça Dì̄ān: G. 301/7)

[= Ey Fużūlì, onun ayağının toprağından habersiz değilim. Ben zamanın Hızır'ıyım ölümsüzlük suyunun yolunu biliyorum.]

Klasik şiir geleneğinde şairler sevgilinin mahallesini ve kapısını Kabe'ye benzetirler. Fużūlì ise sevgilinin mahallesinin ve eşiğinin toprağını Kabe’ye benzetir:

bā'iș-i şevk-i țavāf-i haramem

nisbet-i hāk-i ser-i kū-yi tū şod

(Fużūlì: Farsça Dìvān: G. 194/4)

[= Kabe'yi şevkle tavaf edişimin sebebi senin mahallenin toprağına benzediği içindir.]

èy ruhuñ ḳıble-i cān hāak-i derüñ ka'be-i dil

reh-i 'işḳuñda fenā ser-ḥadi evvel menzil （Fużūlì: Dìivān: G. 175/1)

[= Ey yanağı canın kıblesi, eşiğinin toprağı gönlün Kabesi olan sevgili! Aşkının yolunda ilk konak fena sinırıdır.]

ḩāk-i kūyuñ ka'beye nisbet ḳılan bilmez mi kim

munda her dem anda bir nevbet olur vācib țavāf ～(Fużūlì: Dìvān: G. 148/5)

[= Mahallenin toprağını Kabe'ye benzeten tavafın burada her an orada bir kez gerekli olduğunu bilmiyor mu?]

Sevgilinin ayağının toprağına saçılmaya layık bir mücevher arayışındaki şair, o değerdeki mücevheri bulabilmek için bütün göz yaşlarını tek tek inceler. Beyitte onun ayağının toprağına layık mücevheri bulduğundan söz etmez. Yani sürekli göz yaşı dökmeye devam edeceğini ifade eder:

nișār-i ḩāk-i pāyuñ lāyıḳı bir gevher isterdüm

ḳamu gözden geçürdüm kațre ḳațre eşk-i galțānı

(Fużūlì: Dìvān: G. 266/6)

[= Senin ayağının toprağına saçmaya layık bir mücevher arayışındaydım. Bu yüzden akan bütün göz yaşlarımı damla damla gözden geçirdim.] 
Bazı şerhlerin gubari yazıldığına delil olabilecek (Zülfe 2011: 242) şu beyitte sevgilinin ayağından saçılan tozların keyfiyetinden söz edilmektedir. Beyitte geçen 'keyfiyet, özellik' anlamındaki ḩavāṣ, sevgilin ayağının toprağını yüceltmek amacıyla kullanılmıştır:

havāṣ-i hāak-i pāyuñ şerhini taḥkịk èdüp merdüm

$\dot{g} u b \bar{a} r$ ilen beyāż-i dìde-i hūn-bāre yazmışlar

(Fużūlì: Dìivān: G. 68/2)

[= Halk, ayağından saçılan tozların keyfiyetini iyice tahkik edip toz yazıyla (Gubarî) kan saçan gözün akına yazmışlar.]

\section{Sürme ve Toprak İlgisi}

Sürme, toz halinde olduğu için toprakla ilişkilendirilir. Gözleri yaşartarak gözün görüş gücünü artırdığına inanılır ve tedavi amacıyla da kullanılır. (Onay 1993: 381; Gürer 1997: 119-126) Klasik şiir geleneğinde sevgilinin/memduhun eşiğinin, ayağının, yolunun toprağı gözlerin görüş gücünü artıran sürme olarak vasıflandırılır. Fużūli de bu mazmunu memdunu övmek için kullanır. Bağdat Valisi Ayas Paşa'ya sunduğu kasidede, Paşa'nın Bağdat'a geldiğinde ayağının toprağının halkın ağlamaktan kör olmuş gözlerine sürme olduğunu söyler:

olmışiken eşk seyl-ābiyle a'mā şükr kim

buld çeşm-i mülk hāk-i makdemüñden iktihāal

(Fużūlì: Dìvān: K.13/9)

[= Sel gibi göz yaşı dökmekten ülkenin gözleri kör olmuşken şükür ki senin gelişinle ayağının toprağından gözlere sürme çekildi.]

Aşağıdaki beyitte Fużūlì, göze kaçan toprağın gözleri yaşartması gerçeğinin rağmen sevgilinin mahallesinin toprağının göz yaşlarını dindereceğini söylemiştir:

țabìibā ḩāk-i kūy-i yārdandur eş̧ teskini

bize arturma zaḩmet göz yaşarur tūtiyālardan ～(Fużūlì: Dì̄vān: G. 215/6)

[= Ey tabip! Gözyaşı ancak sevgilinin mahallesinin toprağı ile diner. Bizim rahatsızlığımı artırma; sürme ancak gözleri yaşartır.]

Sevgilinin ayağının tozunu öpmenin hasretiyle göz yaşı döken şair, göze tedavi amacıyla sürülen sürmenin gözleri yaşartmasına benzetiyor:

hoşem kim dem-be-dem giryān gözüm ol hāk-i pādandur

ziyānı olmaz ol göz yaşınuñ kim tūtiyādandur

(Fużūlì: Dìivān: G. 88/1)

[= Gözlerimin sürekli o ayak toprağından dolayı yaş dökmesinden memnunum çünkü sürmeden dolayı göz yaşı dökmenin zararı yoktur.]

Çok göz yaşı döktükçe sevgilinin eşiğinin toprağının gözden akıp gitmesinden endişe ediyor:

h̆āk-i der-gāhuñ nazardan sürme èy seyl-āb-ı eşk

ḳllma żāai sürme-i çeşm-i cihān-bīnüm menüm ～(Fużūlì: Dīvān: G. 206/3)

[= Ey sel gibi akan göz yaşım! Eşiğinin toprağını gözümden uzaklaştırma. Dünyayı gördüğüm gözlerimin sürmesini kaybetme.] 
Aşağıdaki beyitte geçen ġarīb hem 'zavallı, gariban' hem de 'gurbet ellerde kalmış' anlamlarına gelmektedir. Böylece şair, sevgilinin ayağının toprağından uzak kalmayı gurbet olarak nitelendirmiştir. Tarlan'a göre ayak izi ilahi ayetlerdir ve o ayak izini gözlere çekmek o ayetlere eğilip Hakk'ın alametlerini görmektir (Tarlan 1997: 99)

$$
\begin{aligned}
& \text { tūtiyā-yi hāak-i pāyün feyżine yol bulmasam } \\
& \text { nūr-i çeşmüm 'ayb ḳılma kör olur derler ġarīb }
\end{aligned}
$$

[= Ey gözümün nuru sevdiğim! Feyiz almak için ayağının toprağının sürmesine ulaşamazsam beni ayıplama; "Garip kör olur." derler.

Rüzgarlı bir havada toprağın gökyüzüne yükselmesi güneşin sevgilinin ayağının toprağını gözlerine sürme çekme gayreti olarak betimlenir:

$$
\begin{aligned}
& \text { gün çeker yèrden göge her dem ġubār-i rāhuñ } \\
& \text { tūtiyā içün beli gökden yère minnet çeker } \quad \text { (Fużūlì: Dìvān: G. 78/2) }
\end{aligned}
$$

[= Güneş sürekli yolunun tozunu yerden gökyüzüne doğru çeker. Evet, güneş o sürmeyi çekmek için yerden ğöğe sıkıntı çekiyor.]

me-keş ber dìde ey hurşsìd ḩāk-i ān kef-i pā-rā

me-kon bā ḩāk yeksān tūtiyā-i dìde-i māa-rā (Fużūlì: Farsça Dìivān: G. 6/1)

[= Ey güneş! O ayağın toprağını gözlerine çekme. Gözümüzün sürmesini toprak ile bir tutma.]

\section{Şarap Tortusu ve Toprak İlgisi}

Şarap tortusu ve toprak ilişkisi hakkında, XVI. yüzyılda Osmanlı İmparatorluğu'na gelen Alman seyyah Hans Dernschwam'in verdiği şu bilgiler göz önünde tutulmalıdır: "Bu toprak (...) ev yapımında kullanılan bir nevi kireçli topraktır. İstanbul'da bakkallarda satılır, pekmez toprağı denir. Toprakla yapılan bu şarap (...) tatlı üzümden yapılan sert bir içkidir. (...) Kalkerimsi bir toprak kokusu hissedilir.” (Önen 1987: 141, 142). İnsanın topraktan yaratılmış olması ve şarabın tortusunda toprak bulunması sebebiyle Fużūlì, kendisini şarap tortusu ile bir tutar. Fużülì'nin öldükten sonra toprağının şarap tortusu haline gelerek şarap neş'esinin, tasavvufi yönden bakıldığında ilahi aşk zevkinin kalıcı olmasını istediği şu beyitler dikkate değer:

dūr istemen zemānì mey neş'esin başumdan

țoprag olanda yā rab dürd-i mey èt ġubārum (Fużūlì: Dīivān: G. 192/6)

[= Şarap neşesinin bir zaman bile başımdan eksik olmasını istemem. Ya Rabbi, ben toprağa karıştığımda tozlarımı şarap tortusu haline getir.]

rind hāk olsa dahi dürd-i hum-i bāde olur

ne ise koymaz elinden mey-i șahbā etegin （Fużūlì: Dìivān: G. 226/6)

[= Rint ölüp toprağa karışsa bile şarap küpünde tortu olur. Ne olursa olsun kızıl şarapla bağını koparmaz.]

dutar olsam ne 'aceb mey etegin dürd-șıfat

eyleyüpdür nice topraġı bu iksìr țllā

(Fużūli: Dìvān: G. 23/5)

[= Tortu gibi şarabın eteğine yapışsam, onunla dost olmak istesem bunda şaşılacak ne var? Bu iksir nice toprağı altına çevirmiştir.] 


\section{Toprak ile İlgili İfadeler}

başa țoprag șavur-: 'Yas ve matem ifadesi'. (Y1lmaz 2013: 348)

bel olmış idi elinde dırnag

yèrden șavururdı başa țopràg (Fużūlì: Leylā vü Mecnūn: 2240)

[= Mecnun'un elindeki tırnakları bir kürek olmuş yerden başına toprak saçıyordu.]

Başa toprak savurmayı ifade eden hāk ber ser ifadesi 'düşkün; zelil ve ölü' anlamlarına gelmektedir. (Steingass 1998: 441) Bu ifade Farsça Dìvān'da ‘ölmek’ anlamında kullanıyor:

çunān zi dest-i gamet hāk kerdeem ber ser

ki rūz-i haşr ser ez-ḩāk ber ne-h̆vāhem kerd （Fużūli: Farsça Dīvān: G. 134/3)

[= Senin derdinden dolayı başıma öyle toprak saçtım ki mahşer gününde bile başımı topraktan kaldırmayacağım.]

Klasik şiirde daha çok yas nişanesi olarak kullanılan başa toprak saçmak ifadesi Farsça Dìvān'da delilik göstergesi olarak geçiyor:

ḩāk ber-ser mī-konem dìvāne'em

gāh tahtem geşte hāk u gāh tāc （Fużūlìi: Farsça Dìvān: G. 121/6)

[= Ben bir deliyim; başıma toprak saçıyorum. Toprak bazen benim tahtım bazen de tacımdır.]

gözine țoprag dol-: Gözüne toprak dolmak | Ölmek’.

Farsça'da 'umut etmek' anlamında gelen çeşm dāşten (Steingass 1998: 393) ve Türkçedeki 'bir şeyin olmasını veya birinin gelmesini beklemek' anlamındaki gözlemek ibarelerinin etkisiyle ümmìd ve göz kelimelerinin terkip halinde sunulduğu aşağıdaki beyitte umudunu yitirmeyi çarpıcı bir şekilde dile getirmek için 'ölmek' anlamındaki gözüne toprak dolmak deyiminden faydalanılmış:

$$
\begin{aligned}
& \text { ümmidi gözine doldı țoprag } \\
& \text { makṣūd nihāli tökdi yapràg （Fużūlì: Leylā vü Mecnūn: 1719) }
\end{aligned}
$$

[= Umudunun gözüne toprak doldu; arzularının fidanı yaprak döktü.]

hāk: 'toprak'

Aşağıdaki beyitte, kadehin imal edildiği madde olan toprak, hakir görülmek yerine hürmet edilen bir nesne halini almıştır. Çünkü kadeh şarabı icat eden Cem'in toprağından imal edilmiştir. Vefat etmiş birinin kabrine yani toprağına hürmet ona hürmet etmek anlamına gelir. $\mathrm{Bu}$ nedenle sakiye toprak kadehi tutarken edebe aykırı davranmaması tenbih edilir:

$$
\text { hāk-i sāgar cem ü cemşìddür èy pìr-i mugàān }
$$

haber èt sākịye kim dutmaya sāgar güstāhn （Fużūlìi: Dīvān: 59/1)

[= Ey meyhaneci! Kadehin toprağı Cem'in Cemşid'in toprağıdır. Sâkiye söyle de kadehi terbiyeye aykırı bir biçimde tutmasın.]

'memleket, yöre’: 
Şairin Anadolu'ya gitme arzusunu dile getirdiği beyitlerden biri olan şu beyitte Anadolu için diyār kelimesini kullanırken Bağdat için ḩāk kelimesini kullanmasının nedeni sadece toprağın mecazi olarak yöre, memleket anlamlarına gelmesi değildir. İki muhiti kıyasladığında Bağdat'1 Anadolu'ya göre hakir gördüğü için toprak kelimesini tercih ettiğini düşünüyoruz. İlk mısradaki $i z d i y \bar{a} d$, rütbe ve fażl kelimeleriyle Anadolu'yu överken ikinci misrada h̆āk kelimesi ile Bağdat'1 yermektedir:

$$
\begin{aligned}
& \text { Fużūlì ister iseñ izdiyād-i rütbe-i fażl } \\
& \text { diyār-ı rūmı gözet terk-i hăak-i bag̀dād èt }
\end{aligned}
$$

(Fużūlì: Dìvān: G. 41/7)

[= Fużūli, değerinin mertebesi artsın istersen Anadolu diyarına gitmeye bak, Bağdat topraklarını terk et.]

'mezar'

Toprağın 'mezar' anlamında kullanılması yaygın olsa da aşağıdaki beyitte ḩāk kelimesi gül yaprag் $ı$ ile güzel bir tenasüp oluşturmuş. Birinin mezarı başında çok ağlamayı ifade eden mezar taşını lâl taşı ya da gül yaprağı gibi kıpkırmızı hale getirme imajı Fużūlī’nin işlediği orijinal imajlardan biridir. ${ }^{1}$

$$
\begin{aligned}
& \text { bag̀rına bașup mezār-ı pākin } \\
& \text { gül yaprag̀ı e.tdi levḥ-i hăkin (Fużūlì: Leylā vü Mecnūn: 2185) }
\end{aligned}
$$

[= Tertemiz kabrini bağrına bastı. Mezar taşını (göz yaşıyla) gül yaprağı gibi kıpkırmızı hale getirdi.]

hākden baş çek-: 'Başını topraktan kaldırmak; (bitkiler için) baş vermek, boy atmak; yeşermek | Dirilmek'.

'aceb yoh sebze veş ger huākden baş çekse emvātı

'aceb yoh olsa miñ genc-i nihān zähir bu vìrāndan

(Fużūlì: Dìvān: K. 25/24)

[= Bugün (Irak'ta) ölüler yeşillik gibi topraktan baş verseler, dirilseler buna şaşılmaz. Bu viraneden bincelerce saklı hazine çıksa buna şaşılmaz.]

Farsça Dìvān'da başını topraktan kaldırmak ‘dirilmek’ anlamında kullanılıyor:

çunān zi dest-i ġamet ḩāk kerdeem ber ser

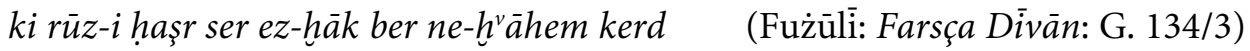

[= Senin derdinden dolayı başıma öyle toprak saçtım ki mahşer gününde bile başımı topraktan kaldırmayacağım.]

hāa çek-: 'Toprak serpmek | Hakir bir duruma düşürmek' .

Peygamber övgüsünde kaleme alınmış aşağıdaki beyitte, Hz. Peygamber'in makamının varlık aleminin en üstünde bulunan feleklere varlık aleminin en altında bulunan toprağ 1 saçtığ 1 söylenerek o makamın felekleri bile hakir düşürdüğü ifade edilmiş:

\footnotetext{
${ }^{1}$ Mesela: ḳabr üzre ahıtdı ḳanlu yaşın / la'l eyledi yaşı ḳabri daşın (Fużūlì: Leylā vü Mecnūn: 2185) [= Kabrinin üzerine kanlı göz yaşlarını döktü ve kabir taşını lâl taşı gibi kıpkırmızı hale getirdi.]
} 
olmış eflāk hāak-i rāhuy

çekmiş eflāke hāk cāhun （Fużūlì: Leylā vü Mecnūn: 174)

[= Felekler yolunun toprağı olmuş. Makamın feleklere toprak saçmış (makamının yüceliği felekleri bile hakir duruma düşürmüş.)]

hāk ol-: ‘Toprak olmak | Ölmek’.

yoluñda intizār-i maḳdemüñule hāk olan çohdur

h̆rām èt bir ḳadem miñ hāak-sārı ser-firāz eyle (Fużūlì: Dīivān: G. 250/5)

[= Seni bekleyerek yolunda can verenler çok. Bir kez salın da binlerce toprak olmuşu yeniden dirilt.]

rind hāk olsa dahi dürd-i humm-i bāde olur

ne ise koymaz elinden mey-i șahbā etegin

(Fużūlī: Dīvān: G. 226/6)

[= Rint ölüp toprağa karışsa bile şarap küpünde tortu olur. Ne olursa olsun kızıl şarapla bağını koparmaz.]

hāk-sār: 'Toprağa benzeyen | zelil'.

hergiz özümi görmemişem beyle bī-şu'ūr

hergiz özümi görmemişem beyle hāk-sār （Fużūlì: Dìivān: K. 37/33)

[= Hiç böyle şuursuz olmamıştım. Hiç bu kadar zelil olduğumu hatırlamıyorum.]

ḩāk-sār èt-: 'Tahkir etmek, aşağılamak'.

ol süleymānuñ şükūhı dive șalmış rüsta-ḩiz

bu süleymān șavleti küffärı ètmiş hāk-sār

(Fużūlì: Dìvān: K. 11/58)

[= O (peygamber) Süleyman'ın yüceliği cinleri emri altına almış, bu (sultan) Süleyman'nın gücü kafirleri tahkir etmiş.]

\section{hāâksārı ser-firāz eyle-:}

Beyitte geçen hāk-sārı ser-firāz eyle ifadesi hem 'hakirleri yücelt' anlamında hem de 'toprak olmuşları, ölüleri dirilt' anlamında başarıyla kullanılmış. Topraktan başını kaldırmayı dirilmek anlamında kullanan Fużūlì, (Bk. ḩākden baş çek-) asıl anlamı 'birinin başını kaldırmak' olan ser-firāz eyle- ifadesini 'diriltmek' anlamında kullanıyor.

yoluñda intizār-i makdemüñle ḩāk olan çohdur

hırām èt bir kadem miñ hāe-sārı ser-firāz eyle (Fużūlī: Dìivān: G. 250/5)

[= Seni bekleyerek yolunda can verenler çok. Bir kez salın da binlerce toprak olmuşu yeniden dirilt.] 
hāk-sār ol-: 'Toprak gibi olmak, toprağa karışmak | Ölmek'.

haste kesmez mi hayātından țama' gitse țabīb

gitse cān olmaz mı cism-i derd-perver ḩāk-sār (Fużūlì: Dìivān: K. 39/12)

[= Hekim gittiğinde hasta hayatından ümit kesmez mi? Can gittiğinde dertli, hasta beden toprağa karışmaz mı?]

hূāk-i reh/rāh: 'Yol toprağı | köle, hizmetkar'.

żāyi geçirmez yāsemīn ömr-i lațî ü nazenīn

ihlās ile eyler özin hāke-i reh-i hayrü’n-nisā （Fużūlì: Dìivān: K. 8/15)

[= Yasemin ince ve nazenin ömrünü boşa geçirmez. Tüm samimiyetiyle kendini kadınların en hayırlısı Hz. Fatıma'ya hizmetkar eyler.]

şehā Fu̇̇ūlì-i üftāde hāak-i rāhuñdur

hemişe naḳd-i hayātı senün yolında nișār ～(Fużūlì: Dìivān: K. 6/45)

[= Şahım Hz. Ali! Düşkün Fużūlì senin hizmetkarındır. Hayat akçesini sürekli senin yoluna saçmışır.]

hāa-i reh-güzār: 'Basıp geçilen toprak | zelil'.

ser-verā bed-h̆vāh ḩāk-i reh-güzār olsun saña

kanda kim 'azm eyleseñ tevfīk yār olsun saña (Fużūlīi Dīvān: K. 15/XI-1)

[= Ey komutan! Düşmanların senin yolunda basıp geçtiğin zelil bir toprak olsun. Nereye gitsen Allah'ın yardımı seninle olsun.]

ḩāk-dān: ‘Toz toprak süpürülen yer, mezbele | dünya’. (Öztürk; Örs 2000: 314)

meskenüñ bezm-gāh-i vaḥdetdür

èy Fużūlì bu hāak-dāndan geç (Fużūlì: Dìvān: G. 50/5)

[= Ey Fużūlì, senin yerin vahdet meclisidir. Bu mezbele dünyadan vaz geç.]

o dem ki bu h̆āk-dāna düşdi

ḥālini bilüp fig̀āna düşdi （Fużūlì: Dìvōan: Leylā vü Mecnūn: 508)

[= Bu dünyaya geldiğinde gelecekteki halini bilip feryat etmeye başladı.]

Maṭla'u'l-i'tikāad'da varlıkların ulvî (yüce) ve süflî (aşağı) varlıklardan ibaret olduğunu, süflî varlıkların en altında toprak olduğunu aktaran Fużūli, (Coşan 2014: 11) şu beytinde toprak ile süflî alemi terkip halinde kullanıyor:

niçün kim hāak-dān-i 'ālem-i süflide 'àdetdür

kemān-dār oh atan sā'at nişānin üstühāan eyler

(Fużūlì: Dìvān: K. 36/12)

[= Nasıl ki süflî alemin en alt tabakası olan yeryüzünde bir nişancının ok atarken kemiğe nişan alması adetse (felek de bana nişan alıyor).] 
reng vèr-: 'Renk vermek; şeklini değiştirmek; aldatmak'.

Feleğin insana reng vermesi, aldatması, toprağa reng vermesine yani toprağın rengini, şeklini değiştirmesine benzetilir. Aşağıdaki her iki örnekte de bunu görüyoruz:

èy gönül 'àleme aldanma saña reng vèrür

hākedür kim anı geh la'l ḳılur gāh hazef （Fużūlì: Dìivān: G. 149/5)

[=Ey gönül, dünyaya kanma. Nasıl toprağı bir lâl taşı bir çömlek haline getiriyorsa seni de şekilden şekle sokar, seni aldatır.]

èy murașşa' tāc mağrūrı olan bil kim felek

her kimi 'ālemde bir reng ile eyler huāk-sār

la'l șanma kim firīb-i firḳa-i ețāl içün

reng vèrmişdür ḳara topraġa devr-i rūzgār

(Fużūlì: Hadīkatü’s-sü'edā: s. 156)

[= Ey taşlarla işlenmiş tacına aldanan! Şunu iyi bil ki felek dünyadaki herkesi bir şekilde zelil eder. Senin lâl taşı sandığın, feleğin çoluk çocuk oynasın diye kara toprağa renk vermesinden başka bir şey değildir.]

türbet: Asıl anlamı 'toprak' olan bu kelime yaygın şekilde 'değerli kişilerin ziyaret yeri haline gelmiş kabri' anlamında kullanılmaktadır. Türbe(t)-türâb (toprak) ilişkisi hakkında şunları söylemek mümkündür: "Türâbın türbe(t) ile kökteş kelimeler oldukları düşünülecek olursa, insan bedeninin dünyadaki son menzilinin toprak olduğunu ve hatırasının da yine toprakla abideleştiğini söylemek mümkün hâle gelir." (Dağlar 2017: 42). Şarabın üzümden yapılması nedeniyle asmaya hürmet edildiği aşağıdaki beyitte geçen rāyiha-i türbet-i pāk ifadesi 'temiz toprağın kokusu' anlamına gelse de 'temiz türbenin kokusu' anlamını da çağrıştırmaktadır. İkinci mısrada geçen dua ifadeleri vefat etmiş evliyalara edilen duaları çağrıştırıyor:

cān vèrür rāyiḥa-i türbet-i pākü̈n èy tāk

nevverallāhu leke'l-erda seḳallāhu șerāk

(Fużūlī: Dīvān: G. 155/1)

[= Ey asma, senin temiz toprağının/türbenin kokusu insana can verir. Allah yerini aydınlatsın ve toprağını sulasın.]

toprah: 'toprak':

anup tenhālugì kabr içre nefret ḳılma ölmekden

țarīk-i üns dut kim her avuç țoprah bir ādemdür （Fużūlì: Leylā vü Mecnūn: 2907)

[= Mezardaki yalnızlığı düşünüp de ölmekten tiksinme. Onunla yakınlık kurmayı dene çünkü her avuç toprak bir insandır.]

'mezar':

her laḥa èdüp fig̀ān ü zārì

țoprağuma èdesen güzār $\quad$ (Fużūlì: Leylā vü Mecnūn: 2148)

[= Sürekli feryat edip göz yaşı dökerek kabrime gelesin.] 
țoprag ol:- 'Toprak olmak | Ölmek’.

Mecazi olarak ölmek anlamında kullanılan bu ifadeyi rakibi olan suyun önünü kesmek amacıyla toprak haline gelmek anlamında kullaniyor.

șu yolın ol kūydan toprag olup dutsam gerek

çün rakīiümdür dahi ol kūya ḳoyman vare șu (Fużūlì: Dìivān: K. 3/12)

[=Toprak olup o mahalleye giden suyun yolunu kesmeliyim. Madem ki su rakibimdir o mahalleye varmasina izin vermem.]

țoprahdan götür-: Farsça'da 'birini kötü bir durumdan kurtarmak; birine şeref ve değer vermek' gibi anlamlara gelen $e z$-ḩāk ber-dāşten ifadesinin (Şamlu 1970: 321) bire bir Türkçe tercümesidir ve şair Türkçe şiirlerinde bu ifadeyi 'şeref vermek; tazim etmek; hürmet etmek' anlamlarında kullanır. Önce Farsça Dìvān'da ifadenin kullanıldığı örneklere bakalım. Gazel formundaki bir naatten alınan aşağıdaki beyitte geçen 'Adem'i topraktan kaldırmıştır' anlamındaki ber-dāşte ez-ḩāk ādem-rā ifadesi hem Adem'in (as) topraktan yaratılmasına hem de ona şeref ve değer verilmesine işaret eder:

zihi feyż-i vucūd ez-pertev-i zāat-i tù 'ālem-rā

kemāl-i kadr-i tū ber-dāşte ez-ḩāk ādem-rāa （Fużūli: Farsça Dì̄vān: G. 4/1)

[= Sen ne yücesin ki âlem varlık bereketini, şahsiyetinin nurundan almıştır. Kıymetinin büyüklügüü Adem'i topraktan kaldırmıştır, ona şeref vermiştir.]

Gölge gibi sevgilinin yoluna düşmüş aşık, güneşe benzeyen sevgilinin lutfuyla topraktan kaldırılmayı istemektedir:

çu sāye ber-reheşuftādeem kārì kon ey țāli‘

ki àyed äftāb-i men me-rā ez-hāk ber-dāred (Fużūlì: Farsça Dìvān: G. 126/6)

[= Gölge gibi onun yoluna düşmüşüm. Ey talih, bir lütuf göster de o güneş gibi sevgilim beni yerden kaldırsin.]

Gelen misafiri karşılamak için 'şeref verdiniz' anlamında da kullanılır:

è mahdūm-zāde șafā getürdün ve bizi țoprahdan götürdüñ (Fużūlì: Hadīkatü’s-süe`dā:: 153)

[= Ey beyzade, safalar getirdin. Bize şeref verdin.]

sen hōoş geldün șafā getürdün

țoprahlardan bizi götürdüñ （Fużūlì: Leylā vü Mecnūn: 1057)

[= Sen hoş geldin safalar getirdin. Bize şeref verdin.]

'Hürmet etmek' anlamındaki bir örnek:

götürün ohların è dìdelerüm toprahdan

bu yarar nesnelerüñ ḳadrini yahşıca bilüñ $\quad$ (Fużūlì: Dìvān: G. 159/3)

[= Ey gözlerim, sevgilinin oklarına hürmet edin. Bu yararlı ve değerli varlıkların kıymetini iyi bilin.] 
țoprahdan götür meni èy eşk-i lāle-gūn

başumdan ètme sāyeni kem èy ḩabāb-ı ḩūn （Fużūlì: Dìivān: G. 231/1)

[= Ey göz yaşı, benim değerimi yücelt; beni zilletten kurtar. Ey kan kabarcığı, lütfunu benden esirgeme.]

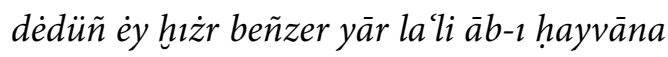

bu ta'zìim ile țoprahdan götürdüñ āb-ı hayvānı (Fużūlì: Dìivān: G. 266/5)

[= Ey Hızır, sevgilinin yakut dudağı hayat suyuna benzer dedin. Böylesi bir hürmetle hayat suyunun değerini artırdın.]

\section{Sonuç}

Klasik şiirin kuralcı ve gelenekçi yapısında herkesin kullandığı söz kalıplarını herkesten farklı yorumlayarak şairler orijinal olmaya gayret ederler. Bu çalışmada Fużūli’’nin sevgilinin eşiğinde toprak olmak gibi şairler tarafından sayısız örneği verilen kalıpları çarpıcı bir şekilde işlediği görülmektedir. Toprakla ilgili deyimlerden sıkça kullanılanları bile kendi zihin dünyasında işleyerek orijinal hale getirmiştir. Bunun yanı sıra başka şairlerde örneklerini tespit edemediğimiz toprakla ilgili deyimler de yer almaktadır. Kimisinin ortak bir kültür havzasından beslenen şairlerin müşterek hayal güçlerininin iki dilli ifadesiyle kimisinin de Farsçadaki örneklerinden ilhamla oluşturulduğunu düşündüğümüz bu deyimleri, şairin Farsça Divān'ından tespit ederek örneklendirmeye çalıştık.

Bir şairi daha iyi anlamak için bütün eserlerine bakmanın daha etkili bir yol olduğunu düşünmekteyiz. Bu çalışmadan hareketle, şairin bir eserinde geçen beytin başka eserlerindeki beyitlerden yola çıkarak daha iyi anlamlandırılabileceği sonucuna ulaşılmıştır. Böylece şairlerin anlam dünyasının, eserlerine bütüncül bakıldığında daha iyi ortaya çıkabileceği anlaşılmıştır.

Çalışmamızın sonucunda Fużūlì'nin toprakla alakalı orijinal mazmunlar oluşturup, toprakla ilgili deyimleri kullanmasındaki tek etkenin gelenek olmadığı görülmektedir. Toprak, şairin kendini hakir gören yapısını iyi ifade eden bir kavramdır. Klasik şairlerin hepsinin kendini hakir gördükleri doğrudur ancak şairin mahlas olarak 'boş konuşan, değersiz' anlamlarına gelen Fużūli'yi seçmesi kendini hakir görmenin onun şiirinde önemli bir yer tuttuğunu düşündürmektedir. Bununla birlikte bu mahlasın 'faziletlere mensup' anlamına gelmesi toprağın -özellikle Kerbelâ toprağının- manevi yönüne de işaret etmektedir. Beyitlerde, sevgilinin eşiğinde veya mahallesinde toprak olmuş aşığın Adem yani insan olması hem hakirliği hem de manevi değeri ifade etmektedir.

\section{Kaynaklar}

Aḥmed Paşa: Dìvān: Tarlan, Ali Nihat. (1996) Ahmed Paşa Divanı, İstanbul: Milli Eğitim Basımevi.

Ataş, Hayri; Güven, Güler. (2009) Ali Nihad Tarlan'dan Divan Şiiri Dersleri, İstanbul: Türk Edebiyatı Vakfı Yayınları.

Coşan, Esat. (1986). Hacı Bektaş-ı Veli Makâlât. İstanbul: Seha Neşriyat.

Coşan, Esat; Işıı, Kemal (çev.) (2004). Fużūli - Matlau'l-I'tikad fi Ma'rifeti'l-Mabda'i ve'l$M a^{\prime} a d$, Önsöz ve notlarla neşre hazırlayan: Muhammed b. Tâvid et-Tancî, İstanbul: Server İletişim. 
Dağlar, Abdülkadir (2017). “Şair Âşığın Toprakla Hâlleşmesi”, Türk Dili Dergisi, 68(792), 4249.

Demirel, Şener (2005). “Abdulbaki Gölpınarlı'nın Kendi Sesinden Mesnevi'nin İlk İki Beytinin Şerhi”, Tasavvuf İlmî ve Akademik Araştırma Dergisi, 6(14 )ss. 365-382.

Eliade, Mircea (2009). Dinler Tarihine Giriş, Çev. Lale Arslan, İstanbul: Kabalcı Yayınları.

Fużūlì: Dìvān: Akyüz, Kenan vd. (1958) Fuż̄uli Türkçe Divan, Ankara: Türk Tarih Kurumu Basımevi.

Fużūlì: Farsça Dìvān: Mazıŏlu, Hasibe (1962). Fużūlī Farsça Divan (Edisyon Kritik) Ankara: Ankara Üniversitesi DTCF Yayınları; [Düzgün] Sadık, Hüseyin Muhammedzâde. (h. 1382) Mevlânâ Hakîm Molla Muhammed Fużūli Bayatlı Dîvân-ı Eş'âr-ı Fârisî, Tebriz: İntişââat-1 Yârân.

Fużūlì: Hadịkatü’s-sü'edā: Güngör, Şeyma (1987) Fużūli, Hadîkatü's-Sü’eda, Ankara: Kültür ve Turizm Bakanlı̆ Yayınları.

Fużūlì: Leylā vü Mecnūn: Doğan, Muhammet Nur. (2000) Leyla ile Mecnun Metin-Düzyazıya Çeviri-Notlar ve Açılamalar, İstanbul Yapı Kredi Yayınları.

Gölpınarlı, Abdulbaki. (1977). Tasavvuftan Dilimize Geçen Deyimler ve Atasözleri, İstanbul: İnkilâp ve Aka Kitabevleri.

Gürer, Abdülkadir. (1997) "Dîvân Edebiyatında Sürme ve Nâilî'nin Bir Gazeli", Türkoloji Dergisi, 12(1), 119-126.

Harmancı, Meriç. (2014). "Kutlu Başlangıçtan Ebedî İstirahatgaha: Türk Tasavvuf Edebiyatında Toprak Algısı" Divan Edebiyatı Araştırmaları Dergisi, 13(13), 23-38.

İnce, Aynur (2012) “Anadolu'da Alevî-Bektaşî Geleneğinde Kerbelâ Toprağının Kullanımı” Acta-turcica Kültürümüzde Toprak Özel Sayısı, 248-258.

İzbudak, Veled Çelebi; Gölpınarlı, Abdulbaki (1960). Mesnevî, Abdülbâkî Gölpınarlı'nın önsözü ile birlikte, İstanbul: MEB Yayınları.

Kılıç, Filiz. (2010) Aşık Çelebi Meşẩirü̉ş-Şu'ara İnceleme - Metin C. 3. İstanbul: İstanbul Araştırmaları Enstitüsü.

Nedīm: Dìvān: Macit, Muhsin. (2016) Nedim Divanı Metin-Tıpkıbasım, Ankara: Atatürk Kültür Merkezi Yayınları.

Onay, Ahmet Talat. (2009) Açıllamalı Divan Şiiri Sözlügü: Eski Türk Edebiyatında Mazmunlar ve İzahı (haz. Cemal Kurnaz), İstanbul: H Yayınları.

Önen, Yaşar (çev.) (1987). İstanbul ve Anadolu'ya Seyahat Günlüğü - Hans Dernschwam, Ankara: Kültür ve Turizm Bakanlığı Yayınları.

Özköse, Kadir (2017). “Ahmed Yesevi’nin Hikmetlerinde Dört Kapı ve Kırk Makam Anlayışı” Akademik İslam Araştırmaları Dergisi, 2(2) s. 99-133.

Revnakoğlu, Cemâlettin Server. (1961) Erzurumlu İbrâhim Hakkı ve Ma 'rifetnâmesi, İstanbul: Ercan Matbaası.

Steingass, Frank [J] (1998). A Comprehensive Persian English Dictionary. Yeni baskı, Beyrut: Librairie du Liban. 
Şamlu, Ahmed (1972). Kitâb-i Kûçe - Câmi' Luğât, Ta'bîrât, Istılâhât ve Darbulmeselhâ-yi Fârsî, C. II, Tahran: İntişârât-1 Mâzyâr.

Tarlan, Ali Nihat (1997). Fużūlì Divanı Şerhi, İstanbul: Akçağ Yayınları.

Tarlan, Ali Nihat (1950). Fużūlīnin Farsça Divânı (Tercümesi) İstanbul: Milli Eğitim Basımevi.

Uludağ, Süleyman (1997). Tasavvuf Terimleri Sözlüğ̈̈, İstanbul: Marifet Yayınları.

Yılmaz, Ozan (2013). "Gelenekten Deyişe” Klasik Türk ve Fars Edebiyatlarının Ortak İfade Biçimlerinden "Başa Toprak Saçmak" Türük Dil, Edebiyat ve Halkbilimi Araştırmaları Dergisi, 1(2).

Zülfe, Ömer (2011). Şiirin İzinde Sözün Gölgesinde Osmanlı Şiirinden Kelimeler, Kavramlar, Deyimler, İstanbul: Bilge Kültür Sanat. 